\title{
Effect of short-term feed restriction on temporal changes in milk components and mammary lipogenic gene expression in mid-lactation Holstein dairy cows
}

\author{
A. M. Abdelatty, ${ }^{*} †$ M. E. Iwaniuk, ${ }^{*}$ M. Garcia, ${ }^{*}$ K. M. Moyes, ${ }^{*}$ B. B. Teter, ${ }^{*}$ P. Delmonte, $\ddagger$ A. K. G. Kadegowda, ${ }^{*}$ \\ M. A. Tony, † F. F. Mohamad,† and R. A. Erdman*1 \\ *Animal and Avian Sciences Department, University of Maryland, College Park 20742 \\ †Nutrition and Clinical Nutrition Department, Faculty of Veterinary Medicine, Cairo University, Cairo, Egypt 12211 \\ ¥Food and Drug Administration, College Park, MD 20740
}

\section{ABSTRACT}

Investigations of the temporal changes in mammary gene expression that occur during sudden diet change have been limited by the use of mammary tissue as the source of RNA because of the invasive nature of mammary biopsy procedures. However, the cytosolic crescent, present in $1 \%$ of the largest milk fat globules, contains mammary epithelial cell RNA that has become trapped between the inner and outer milk fat globule membranes during final formation and secretion of milk fat into the lumen of the mammary alveoli. We hypothesized that cytosolic crescent RNA extracted from milk fat could be used as an alternative source of mammary epithelial cell RNA to measure the immediate temporal changes in gene expression as a result of changes in diet. In this experiment, feed restriction was used to mimic the state of negative energy balance observed in early lactation and induce a rapid change in milk fat yield and lipogenic gene expression. Ten multiparous Holstein dairy were fed a basal diet ad libitum during a 14-d preliminary period followed by a 4-d experimental period where 5 cows remained on ad libitum feeding and 5 cows were fed at $60 \%$ of their d 8-14 intakes (restricted) on d 15 to 18 and then returned to ad libitum feeding on d 19 to 21. Milk samples were collected from each milking on d 13 to 20 and the milk fat was immediately isolated, mixed with Trizol LS, and stored at $-80^{\circ} \mathrm{C}$ for subsequent extraction of RNA that was used for measurement of gene expression. Feed restriction tended to increase milk fat percentage. However, total milk and milk fat production were reduced by 21 and 18\%, respectively. Consistent with increased use of body fat for milk synthesis, serum nonesterified fatty acids increased 6 -fold $(0.78 \mathrm{mEq} / \mathrm{L}$ in the feed restriction vs. $0.13 \mathrm{mEq} / \mathrm{L}$ ad libitum group),

Received March 3, 2016.

Accepted November 26, 2016.

${ }^{1}$ Corresponding author: erdman@umd.edu whereas the milk fatty acids $<\mathrm{C} 16$ decreased and $\geq \mathrm{C} 16$ increased by 6.5 percentage units. The lipogenic genes $A C A C A, F A S N$, and $S C D 1$, and the transcription factor $S R E B F 1$ were downregulated by $59,36,35$, and $43 \%$, respectively, during the feed restriction period. In addition, effects of feed restriction by day within period were detected for the genes AGPAT6, GPAM, BTN1A, and $S R E B F 1$, suggesting that temporal (day-to-day) changes in gene expression could also be detected. The results of this experiment were consistent with previous feed restriction studies in which researchers used the mammary biopsy technique to study gene expression in the mammary gland. We concluded that RNA isolated from milk fat could be used as an alternative approach to investigate rapid temporal changes in lipogenic gene expression.

Key words: dairy cattle, cytosolic crescent, gene expression

\section{INTRODUCTION}

Milk fat synthesis in the dairy cow is controlled by many factors including diet, stage of lactation, season, breed, haplotype, and animal physiological status (Samková et al., 2012). Postruminal infusion of the rumen biohydrogenation intermediate trans-10, cis-12 conjugated linoleic acid in dairy cows was shown to induce an almost 50\% reduction in milk fat yield and similar reductions in mammary lipogenic gene expression within 5 d (Baumgard et al., 2002). Immediately after calving, the expression of genes associated with milk fat synthesis increases rapidly (Bionaz and Loor, 2008a,b) during a period when cows are in a negative energy balance. This period of negative energy balance is thought to provide mobilized long-chain fatty acids (FA) that result in increased milk fat concentration immediately after calving (Kay et al., 2005), which declines thereafter until cows reach peak milk production. The rapidity of these observed changes in milk fat concentration suggests that changes in mammary gene expression are also rapid and likely occur within the 
first 1 to $2 \mathrm{~d}$ following changes in diet and physiological state.

Currently, mammary gland tissue biopsy (Farr et al., 1996) is the most common technique to obtain RNA for further analysis of gene expression in mammary cells. However, due to the invasive nature of the biopsy procedure, a 3- to 4-wk recovery period is required between biopsy samples to allow for healing within the sampled mammary gland, and more frequent sampling on the same cow is typically done on alternate rear quarters (Farr et al., 1996; Moyes et al., 2014). These limitations prevent the measurement of rapid temporal ( 1 to $2 \mathrm{~d}$ ) changes in mammary gene expression that are likely to occur with changes in diet (Baumgard et al., 2002; Nielson et al., 2003) and physiological state (Bionaz and Loor, 2008a,b) of the dairy cow.

One potential alternative to the use of biopsied tissues is to collect and extract RNA from the milk fat. In the dairy cow, the very largest milk fat globules contain a cytosolic crescent that was first identified by Wooding et al. (1970). The cytosolic crescent contains a portion of the mammary epithelial cell cytosol that has become trapped between the inner and outer milk fat globule membranes during final formation and secretion of milk fat into the lumen of the mammary alveoli (Huston and Patton, 1990). A comparative study of milk from several species (Janssen and Walstra, 1982) reported that rabbit had the greatest and cow had the least proportion of fat globules with cytosolic crests. Less than $1 \%$ of milk fat globules in cow milk contain a cytosolic crescent (Janssen and Walstra, 1982; Huston and Patton, 1990), and there is little information on the effects of fat concentration, breed, stage of lactation, and so on, on the proportion of fat globules with cytosolic crescents in dairy cows. In goats, Brenaut et al. (2012) was able to obtain sufficient RNA in just 500 $\mu \mathrm{L}$ of milk fat to conduct extensive gene expression studies. Thus, even with the relatively low abundance of cytosolic crescents in cow milk compared with other species, RNA isolated from milk fat should contain more than adequate amounts of RNA to study gene expression because of the massive amounts of milk fat produced by the dairy cow.

Short-term feed restriction has been used to induce negative energy balance during an established lactation and induces rapid increases in milk fat concentration while reducing milk fat yield (Nielsen et al., 2003; Gross et al., 2011a). We were interested in the effects of feed restriction on the temporal changes in lipogenic gene expression. Our hypothesis was that cytosolic crescent RNA trapped in milk fat globules could be used to detect rapid changes lipogenic gene expression associated with changes in milk fat synthesis during feed restriction. Therefore, the objective of this study was to determine if temporal changes in lipogenic gene expression, which corresponded to changes in milk fat secretion during short-term feed restriction in lactating dairy cows, could be detected using RNA extracted from milk fat.

\section{MATERIALS AND METHODS}

\section{Research Facility and Animals}

All of the experiment procedures for this study were approved by the University of Maryland Institutional Animal Care and Use Committee. The experiment was conducted at the Clarksville Dairy Research Facility (Ellicott City, MD). Ten multiparous Holstein dairy cows averaging $39.3( \pm 4.0) \mathrm{kg}$ of milk and $84( \pm 17)$ DIM were used in a 20-d experiment. Cows were individually housed and fed in tiestalls fitted with water mattresses (Ryder Supply Company, Chambersburg, PA) that were bedded with sawdust. Cows had free access to a shared water source between stalls and were milked twice daily at 0600 and $1600 \mathrm{~h}$.

\section{Diets and Treatments}

All cows were fed a basal diet that contained $65 \%$ forage and $35 \%$ concentrate (DM basis; Table 1) and that was formulated to meet or exceed NRC (2001) nutrient requirements for a $650-\mathrm{kg}$ cow producing $40 \mathrm{~kg}$ of milk containing $3.7 \%$ fat and $3.0 \%$ protein. The forage portion of the diet contained a mixture of alfalfa hay, rye silage, and corn silage, whereas the concentrate portion consisted of ground corn, soybean meal (48\% CP; asfed basis), and a vitamin-trace mineral mix. Cows were individually fed the diet as a TMR. Amounts of feed offered and feed refusals were measured once daily at 0900 h. Diet nutrient composition is shown in Table 2.

This study was conducted and analyzed as a completely randomized repeated-measures design that lasted $20 \mathrm{~d}$ in total and contained 2 dietary treatment levels: restricted feeding (Res) and ad libitum feeding (Ad-Lib). The study was segmented into 3 periods: covariate (COV; d 0 to 14), experimental (EXP; d 15 to 18), and post-restriction (POST; d 19 to 20). During the COV period, all cows were fed the same basal diet ad libitum to estimate baseline daily DMI, which was used as a covariate in the statistical analysis to remove individual cow variation in the statistical model. During the EXP period (d 15 to 18), 5 cows (Res) were immediately fed at $60 \%$ of their d 8 to 14 daily DMI and the remaining 5 cows continued to be fed Ad-Lib. During the POST period, feed restriction ended and all 
cows were fed Ad-Lib to investigate potential carryover effects of the EXP period. Cows were weighed on $\mathrm{d} 8$ and 20 of the experiment.

\section{Sample Collection and Analysis}

The amounts of feed offered and feed refusals were weighed and recorded daily. Individual samples of feed ingredients and the vitamin-mineral premix (corn gluten meal and remaining vitamin and mineral supplements) were collected twice during the experimental period $(\mathrm{d}$ 15 and 20), and composited samples were analyzed by

Table 1. Ingredient composition of the basal diet (\% DM basis)

\begin{tabular}{|c|c|}
\hline Ingredient & $\%$ of $\mathrm{DM}$ \\
\hline Alfalfa hay & 11.34 \\
\hline Rye silage & 12.51 \\
\hline Corn silage & 41.29 \\
\hline Ground corn & 14.67 \\
\hline Soybean meal (48\%) & 11.84 \\
\hline SoyPlus $^{1}$ & 2.99 \\
\hline Corn gluten meal $(60 \%)$ & 0.63 \\
\hline Limestone $^{2}$ & 0.93 \\
\hline Calcium phosphate ${ }^{3}$ & 0.38 \\
\hline Magnesium oxide & 0.14 \\
\hline Sodium bicarbonate & 0.50 \\
\hline Dynamate $^{4}$ & 0.13 \\
\hline Salt & 0.50 \\
\hline Diamond V Yeast Culture $\mathrm{XP}^{5}$ & 0.25 \\
\hline TM- $433^{6}$ & 0.03 \\
\hline 4-Plex $C^{7}$ & 0.01 \\
\hline ADE $\mathrm{Mix}^{8}$ & 0.03 \\
\hline Vitamin $\mathrm{E}^{9}$ & 0.01 \\
\hline Selenium ${ }^{10}$ & 0.06 \\
\hline Megalac $^{11}$ & 1.53 \\
\hline Omnigen- $\mathrm{AF}^{12}$ & 0.19 \\
\hline Rumensin- $22,{ }^{13} \mathrm{~g} / \mathrm{kg}$ & 0.05 \\
\hline
\end{tabular}

${ }^{1}$ SoyPlus West Central Cooperative (Ralston, IA).

${ }^{2}$ Contained $36 \% \mathrm{Ca}$ and $0.02 \% \mathrm{P}$.

${ }^{3}$ Contained $17 \% \mathrm{Ca}$ and $21 \% \mathrm{P}$.

${ }^{4}$ Contained $11.5 \% \mathrm{Mg}, 18 \% \mathrm{~K}$, and $22.5 \% \mathrm{~S}$ (Mosaic Co., Plymouth, $\mathrm{MN})$.

${ }^{5}$ Contained Saccharomyces cerevisiae plus growth medium (Diamond V Mills Inc., Cedar Rapids, IA).

${ }^{6}$ Contained $0.16 \% \mathrm{Co}, 4.0 \% \mathrm{Cu}, 3.0 \% \mathrm{Fe}, 0.35 \% \mathrm{I}, 0.15 \% \mathrm{Mn}$, and $16 \%$ Zn (Southern States Cooperative Inc., Richmond, VA).

${ }^{7}$ Contained $0.20 \% \mathrm{Co}, 0.99 \% \mathrm{Cu}, 0.031 \% \mathrm{Fe}, 1.57 \% \mathrm{Mn}$, and $2.83 \% \mathrm{Zn}$ (Zinpro Corporation, Eden Prairie, MN).

${ }^{8}$ Contained 5,454,545 IU $/ \mathrm{kg}$ of vitamin A, 1,818,128 IU/ $\mathrm{kg}$ of vitamin $\mathrm{D}$, and $9,091 \mathrm{IU} / \mathrm{kg}$ of vitamin $\mathrm{E}$.

${ }^{9}$ Contained $56,818 \mathrm{IU} / \mathrm{kg}$ of vitamin E.

${ }^{10}$ Contained $0.3 \mathrm{IU} / \mathrm{g}$ Se, $28 \%$ Ca.

${ }^{11}$ Contained 9\% $\mathrm{Ca}$ and $84.5 \%$ Fat (Church \& Dwight Co. Inc., Piscataway, NJ).

${ }^{12}$ Contained (per kilogram): $0.41 \mathrm{mg}$ of biotin, $15 \mathrm{mg}$ of choline, 31 $\mathrm{mg}$ of D-pantothenic acid, $1.4 \mathrm{mg}$ of folic acid, $3.2 \mathrm{mg}$ of menadione, $102 \mathrm{mg}$ of niacin, $30 \mathrm{mg}$ of riboflavin, $4.5 \times 10^{10} \mathrm{cfu}$ of Saccharomyces cerevisiae, $15.5 \mathrm{mg}$ of thiamine, $8.2 \mathrm{mg}$ of vitamin $\mathrm{B}_{6}$, and $41 \mathrm{mg}$ of vitamin $\mathrm{B}_{12}$ (Prince Agri Products Inc., Quincy IL).

${ }^{13}$ Contained $20 \%$ monensin sodium, $1 \%$ mineral oil, and carriers as rice hulls, limestone, and fermentation nutrients (Elanco, Greenfield, IN).
Table 2. Chemical composition of the basal diet (DM basis)

\begin{tabular}{lc}
\hline Item & Value \\
\hline $\mathrm{DM}, \%$ & 43.8 \\
$\mathrm{NE}_{\mathrm{L}}, \mathrm{Mcal} / \mathrm{kg}$ & 1.63 \\
$\mathrm{CP}, \%$ & 16.5 \\
$\mathrm{ADF}, \%$ & 20.3 \\
$\mathrm{NDF}, \%$ & 31.2 \\
Lignin, \% & 3.3 \\
Ash, \% & 7.8 \\
$\mathrm{Ca} \%$ & 0.98 \\
$\mathrm{P}, \%$ & 0.45 \\
$\mathrm{~K}, \%$ & 1.85 \\
$\mathrm{Na}, \%$ & 0.46 \\
$\mathrm{~S}, \%$ & 0.22 \\
$\mathrm{Cl}, \%$ & 0.83 \\
$\mathrm{Mg}, \%$ & 0.28 \\
$\mathrm{Fe}, \mathrm{mg} / \mathrm{kg}$ & 221 \\
$\mathrm{Mn}, \mathrm{mg} / \mathrm{kg}$ & 69 \\
$\mathrm{Zn}, \mathrm{mg} / \mathrm{kg}$ & 74 \\
$\mathrm{Cu}, \mathrm{mg} / \mathrm{kg}$ & 21 \\
\hline
\end{tabular}

Cumberland Valley Analytical Services (Hagerstown, MD). Diet nutrient composition is presented in Table 2.

Blood samples from each cow were collected by tail venipuncture in $10-\mathrm{mL}$ evacuated plain tubes, at $0800 \mathrm{~h}$ on d 14, 16, 18, and 20. Serum was separated according to Quiroz-Rocha et al. (2009), and stored at $-20^{\circ} \mathrm{C}$. Serum nonesterified fatty acids (NEFA) were measured by the colorimetric method using NEFA-HR-(2) kits (Wako Life Sciences Inc., Mountain View, CA).

Milk yield was recorded electronically at each milking. Milk samples were collected from each cow at each milking from d 12 through the end of the experiment and analyzed individually for fat, protein, other solids (OS; lactose plus minerals), SCC, and MUN by Lancaster DHIA (Manheim, PA). Milk samples for FA analysis were collected on d 14, 18, and 20 and stored at $-20^{\circ} \mathrm{C}$. Reported milk concentrations and yield of milk components were weighted according to milk yield and composition of milk collected at each individual milking.

Five hundred microliters of whole milk from each sample was freeze-dried and used for FA analysis. Fatty acid methyl esters were extracted using a modified Folch procedure (Christie, 1982), using tri-nonadecenoin (C19:1; Nu-Chek Prep Inc., Elysian, MN) as internal standard (Piperova et al., 2002) and pentadecanoic acid methyl ester (C15:0; Nu-Chek Prep Inc.) as external standard. Fatty acid methyl esters were quantified using a gas chromatograph (Agilent 6890, Agilent Technologies, Santa Clara, CA), equipped with a Supelco 2560 capillary column $(100 \mathrm{~m} \times 0.25 \mathrm{~mm} \times 0.25 \mu \mathrm{m}$, Supelco, Bellefonte, PA) and a flame-ionization detector. The column was maintained at $173^{\circ} \mathrm{C}$ isothermal. Hydrogen was used as carrier gas (constant flow at 30 $\mathrm{mL} / \mathrm{min}$ ) with a linear velocity of $26 \mathrm{~cm} / \mathrm{s}$ and split 
ratio of 1:100. The injection port and detector were maintained at $250^{\circ} \mathrm{C}$, and the detector airflow was 400 $\mathrm{mL} / \mathrm{min}$. Helium make-up gas was used at $30 \mathrm{~mL} / \mathrm{min}$. Individual FA and 18:1 isomers were identified using a Gas-Liquid Chromatography (GLC-463) standard mixture (Nu-Chek Prep Inc.). Fatty acids were quantified with Agilent Chemstation. Short- and medium-chain FA were analyzed as FA butyl esters (FABE), which were mathematically converted to FAME, using C14:0 measured in both procedures, and normalized to the FAME chromatogram. The original FABE procedure of Gander et al. (1962) was modified as follows. Milk samples $(500 \mu \mathrm{L})$ were freeze-dried and then heated in screw-capped glass test tubes, at $80^{\circ} \mathrm{C}$ for $1 \mathrm{~h}$ in the presence of $1 \mathrm{~mL}$ of butyl alcohol and $80 \mu \mathrm{L}$ of concentrated $\mathrm{H}_{2} \mathrm{SO}_{4}$, followed by extracting with hexane in the presence of saturated $\mathrm{KCl}$ and distilled water. Samples were then centrifuged at $500 \times g$ for 5 min at room temperature. Aliquots of the upper hexane layer, containing FABE, were injected directly into Agilent 6890N GLC (Agilent Technologies., Wilmington, DE) equipped with a split injector, a flame ionization detector, and a $30-\mathrm{m} \times 0.25-\mathrm{mm} \times 0.25-\mu \mathrm{m}$ fused silica capillary column coated with HP-5MS (Hewlett-Packard, Avondale, PA). Hydrogen was used as the carrier gas at a flow rate of $1 \mathrm{~mL} / \mathrm{min}$ with a split ratio of $1: 100$ and linear velocity of $23 \mathrm{~cm} / \mathrm{s}$. Injector temperature and detector temperature were set at $300^{\circ} \mathrm{C}$, and column temperature started at $100^{\circ} \mathrm{C}$. The ramp was set at $10^{\circ} \mathrm{C} / \mathrm{min}$ to $250^{\circ} \mathrm{C}$ followed by $6^{\circ} \mathrm{C} / \mathrm{min}$ to $300^{\circ} \mathrm{C}$, and finally held at 300 for $40 \mathrm{~min}$. Standard mixtures, including GLC-60 (Nu-Chek Prep Inc.), were converted to FABE to aid in the identification and quantification of components.

\section{Milk Samples for RNA Collection and Isolation Procedures}

Starting from the p.m. milking of d 14 until the end of the experiment, milk samples $(50 \mathrm{~mL})$ were collected from each cow. A representative sample was collected from the whole milk stream of each individual cow using DHIA-approved sampling containers affixed to milk meters. Individual milk samples were transferred to 50-mL RNase-free centrifuge tubes (Corning Life Sciences, Corning, NY) and placed on ice immediately after milking was completed on each cow. Sample collection in the milking parlor typically took $10 \mathrm{~min}$. After the last milk sample was collected, samples were immediately centrifuged at $2,000 \times g$ for $10 \mathrm{~min}$ at $4^{\circ} \mathrm{C}$ (AccuSpin 3R, Thermo Fisher Scientific Inc., Waltham, MA). One gram of the upper cream layer was scoped with a sterile spatula and transferred to RNase-free 15$\mathrm{mL}$ centrifuge tubes containing $4 \mathrm{~mL}$ of ice-cold Trizol
LS (Invitrogen Life Technologies Inc., Carlsbad, CA). The mixture was vortexed vigorously to disperse the cream layer into the Trizol, snap frozen in liquid $\mathrm{N}$, and stored at $-80^{\circ} \mathrm{C}$ until extraction of RNA. Recognizing the inherent presence of RNase activity in milk, our goal was to minimize time between initial sample collections and snap freezing to maximize RNA integrity. At least 2 people were present during milk sampling and processing and it typically took $30 \mathrm{~min}$ or less from the time of collection until the last sample was snap frozen.

Total RNA was extracted using Qiagen RNeasy lipid tissue mini-kits with On-Column DNase digestion according to manufacturer instructions (Qiagen, Valencia, CA). Contaminant genomic DNA was removed with a DNase enzyme (RNase-free DNase set, Qiagen). The RNA concentration and purity were measured by ND-1000 spectrophotometer (Nano-Drop, Wilmington, $\mathrm{DE}$ ). The RNA purity (absorbance ratio, $\mathrm{A}_{260} / \mathrm{A}_{280}$ ) for all samples was $>1.9$. One gram of milk fat resulted in a mean RNA yield of $7.02( \pm 0.87) \mu \mathrm{g}$ that was collected in $30 \mu \mathrm{L}$ of RNase-free water.

Integrity of RNA was analyzed using StandardSens kit (StdSens, Bio-Rad Laboratories Inc., Hercules, CA) using chip-based micro-capillary electrophoresis system (Experion, Bio-Rad Laboratories Inc.), following manufacturer instructions. The RNA quality indicator (RQI) averaged $7.14 \pm 0.67$. Complementary DNA was synthesized using $500 \mathrm{ng}$ of RNA (using iScript cDNA synthesis kits; Bio-Rad Laboratories Inc.) according to the manufacturer's instructions and samples were stored at $-20^{\circ} \mathrm{C}$. The reaction contained $4 \mu \mathrm{L}$ of $5 \times$ reaction mix [a blend of oligo (dT) and random hexamer primers] optimized for production of targets $<1 \mathrm{~kb}$ in length, 1 $\mu \mathrm{L}$ of reverse transcriptase $\left(\mathrm{RNase} \mathrm{H}^{+}\right)$, and variable volumes of RNA template and nuclease-free water to supply $500 \mathrm{ng}$ of RNA. The reaction was performed in a T100 Thermal cycler (Bio-Rad Laboratories Inc., Hercules, CA) with a temperature program of $25^{\circ} \mathrm{C}$ for $5 \mathrm{~min}, 42^{\circ} \mathrm{C}$ for $30 \mathrm{~min}$, and $85^{\circ} \mathrm{C}$ for $5 \mathrm{~min}$ and then held at $4^{\circ} \mathrm{C}$.

\section{Gene Selection and Quantitative PCR Analysis}

Primer sequences of the mammary lipogenic genes of interest and reference genes were selected from previous publications and are summarized in Table 3. Lyophilized primers $(\sim 25 \mathrm{nmol}$ of DNA oligo, with a standard desalting purification method) were obtained from Integrated DNA Technologies (Coralville, IA). Primers were reconstituted with RNase-free water (Ultra-Pure Distilled Water, Invitrogen). Efficiency of primer was evaluated using pooled RNA sample $(1 \mu \mathrm{g})$ reverse transcribed to cDNA, using the same kit and temperature 
Table 3. Forward and reverse primers used in quantitative PCR analysis

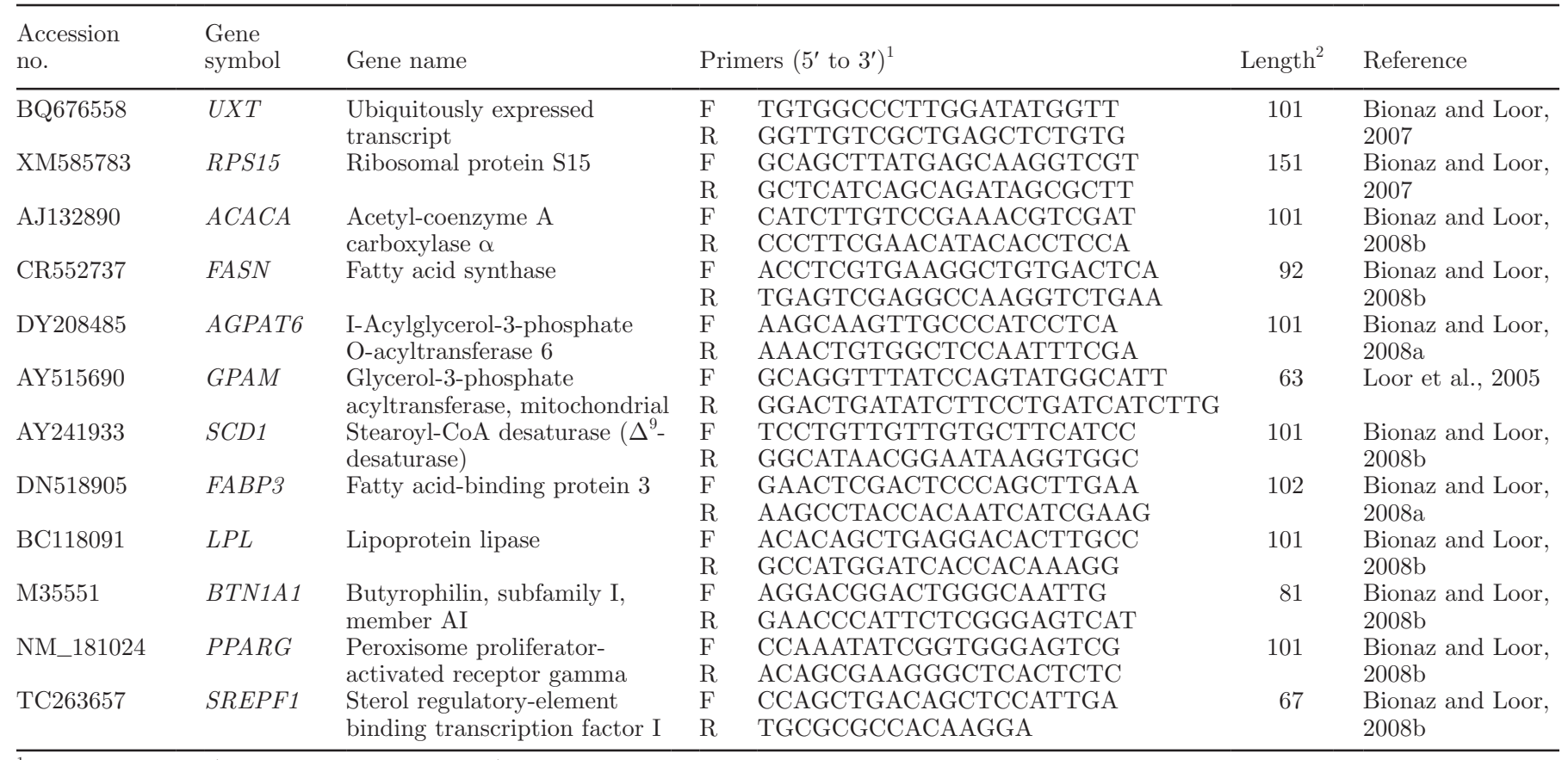

${ }^{1}$ Primer direction $(\mathrm{F}=$ forward; $\mathrm{R}=$ reverse $)$.

${ }^{2}$ Amplicon size in base pairs.

protocol mentioned above and then diluted 1:20 using RNase-free water. Efficiency of primers was verified by 5-point serial dilution (1:4). Quantitative PCR reaction was performed in 96-well plates (VWR International LLC, Radnor, PA), where every well contained $4 \mu \mathrm{L}$ of the sample, $0.5 \mu \mathrm{L}$ each of $10 \mu M$ forward and reverse primer and $5 \mu \mathrm{L}$ of iTaq Universal SYBR Green PCR Supermix (Bio-Rad Laboratories Inc.). The positive reaction was performed in triplicate as well as a nontemplate sample (RNA-free water), used as a control to detect RNA contamination and primer dimers. Runs were performed in Bio-Rad CFX Connect Real-Time PCR Detection System (Bio-Rad Laboratories Inc.). The efficiency equation used was $\left[\left(10^{(-1 / \text { Slope })}\right)-1\right]$, with efficiency values ranging from 0.88 to 1.04 and $\mathrm{R}^{2}$ ranging from 0.98 to 0.99 .

Quantitative PCR of samples was performed in a similar way to that for the primer efficiency test, as described above. The PCR reaction was performed in CFX Connect Real-Time PCR Detection System (Bio-Rad Laboratories Inc.) using the following cycling protocol: initial desaturation at $95^{\circ} \mathrm{C}$ for $30 \mathrm{~s}, 40 \mathrm{PCR}$ cycles at $95^{\circ} \mathrm{C}$ for $5 \mathrm{~s}$ (denaturation) and $60^{\circ} \mathrm{C}$ for $30 \mathrm{~s}$ (data collection, annealing, and extension), and then a final step at $95^{\circ} \mathrm{C}$ for $10 \mathrm{~s}$ before the melting curve. The melting curve (dissociation) step was included to verify absence of primer dimers and formation of single PCR product using an incremental temperature of $0.5^{\circ} \mathrm{C}$ from $65^{\circ} \mathrm{C}$ to $95^{\circ} \mathrm{C}$ for $5 \mathrm{~s}$. The quantification cycle $(\mathbf{C q})$ values of candidate genes were normalized to the geometric mean of the $\mathrm{Cq}$ values of 2 housekeeping genes: ubiquitously expressed transcript (UXT) and ribosomal protein S15 (RPS15), which were selected based on the previous work of Bionaz and Loor (2007). Fold change in gene expression relative to the data collected for the Ab-Lib treatment during the EXP period was calculated using $2^{-\Delta \Delta \mathrm{Ct}}$ method (Livak and Schmittgen, 2001).

\section{Statistical Analysis}

Statistical analysis was completed using SAS software (version 9.3, 2011; SAS Institute Inc., Cary, NC). The number of cows used the experiment was based on power analysis using the POWER procedure in SAS to provide sufficient observations to achieve an $80 \%$ probability of detecting a $300 \mathrm{~g} / \mathrm{d}$ difference in fat yield and a 2-fold difference in FASN gene expression using standard deviations derived from previous work of Vyas et al. (2013).

Data collected during the COV period for each response variable was used as covariate data for its respective response variable in the statistical model to remove individual cow variation from residual error. Mean data for milk yield and milk composition were analyzed as a repeated-measures design using the MIXED procedure in SAS. Effects of treatment (Res, Ad-Lib), milking 
time (a.m., p.m.), period (EXP, POST), and day within period (EXP: d 15 to d 18; POST: d 19 to d 20) as well as all possible interaction terms were considered fixed factors in the model, whereas covariate and cow effects were considered random factors. The individual cow was the subject in the study, with day within period as the repeated element. Based on a comparison of corrected Akaike information criteria (AICC) values from several different variance-covariance matrix structures, all variables were analyzed using a compound symmetric variance-covariance matrix because it yielded the lowest AICC value for each variable.

Energy balance calculations were calculated as follows: Energy intake $\left(\mathrm{NE}_{\mathrm{L}}\right)$ was calculated as DMI $\times$ $1.63 \mathrm{Mcal}$ of $\mathrm{NE}_{\mathrm{L}}$ per $\mathrm{kg}$ of DM (Table 2). Maintenance energy requirements $\left(0.08 \times \mathrm{BW}^{0.75} ; \mathrm{NRC}, 2001\right)$ for individual cows were based on their d-8 BW measured at the end of the preliminary period. Milk energy was calculated using NRC (2001) formula based on fat, protein, and lactose (OS minus 0.70\%) concentrations and yields. Energy balance was calculated as $\mathrm{NE}_{\mathrm{L}}$ intake minus milk energy and estimated maintenance requirements.

Dry matter intake, energy balance, and NEFA were all analyzed as a completely randomized repeated-measures design in PROC MIXED of SAS using the same model as described above except that milking time and its interactions were not included in the model. For gene expression data, milking time effects and its interactions were found to be nonsignificant and therefore milking time was dropped from the model. Fold changes in gene expression relative to the Ad-lib group during the EXP period were calculated and then covariately adjusted for differences in gene expression among individual cows during the COV. The model included the effects of treatment (Res, Ad-Lib), period (EXP, POST), and day within period (EXP: d 15 to d 18; POST: d 19 to d 20) as well as all possible interaction terms that were considered fixed factors in the model, whereas covariate and cow effects were considered random factors.

Due to the relatively poor quality $(\mathrm{RQI}<5)$ of RNA extracted from milk samples from one cow in the AdLib group (that we attribute to an incorrect centrifuge temperature during the RNA extraction process), gene expression data for that cow during the covariate period could not be calculated. Therefore, gene expression data for that cow were missing and not included in the statistical analysis. Additionally, the Cook's D test was used to detect and remove outliers from the gene expression data ( $6.8 \%$ of total) using a value of 0.25 , which is typically used as a cutoff. We cannot explain the relatively high numbers of outliers in this data set. However, we have used the procedures described for milk collection and RNA extraction in subsequent experiments with very few outliers.

Milk FA composition was measured only on d 14, 18, and 20, the final days of the COV, EXP, and POST periods, respectively, with d-14 data used as covariate in the statistical model. Milking time had no effect on milk FA composition. Therefore, statistical analysis of milk FA data was done via analysis of covariance, where the statistical model included the effects of covariate, treatment (Res, Ad-Lib), and period (EXP, POST) in the MIXED procedure (Littell et al., 1996). All means reported are least squares means, and significance was declared at $P<0.05$. Trends toward significance are discussed at $0.05<P<0.10$. Tukey adjustment was used as the multiple mean comparison test to determine significance of all pair-wise comparisons.

\section{RESULTS}

\section{Intake and Milk Production}

By design, DMI was reduced $9.6 \mathrm{~kg} / \mathrm{d}$ by Res during the EXP period $(P<0.01)$, equivalent to a $39 \%$ reduction relative to the Ad-Lib treatment. Dry matter intake was not different between treatments during the 2-d POST period (Table 4, Figure 1).

Milk yield was decreased $8.2 \mathrm{~kg} / \mathrm{d}$ by feed restriction (32.4 and $41.2 \mathrm{~kg}$ for Res and Ad-Lib, respectively; $P=$ 0.01 , Table 4). Most of the decline in milk yield (Figure 2) for the Res group occurred during the second day (d 16) of feed restriction, and milk yield had only begun to recover on d 20 during the POST period [treatment by day (period) interaction, $P=0.01$, when Res cows returned to ad libitum feeding. We detected a trend $(P$ $=0.09)$ for increased milk fat percent in the Res treatment during the EXP period. However, this difference was solely due to differences during the p.m. (1600 h) milking at d 16 [treatment by day by time (period) interaction, $P=0.01$; Figure 3$]$ as milk fat concentration did not differ between Ad-Lib and Res in the a.m. milk throughout the EXP and POST periods. In the Res group and during the p.m. milking, the full magnitude of the increase in milk fat percent was reached by the second day of feed restriction but by d 20 of the POST period, milk fat percent returned to Ad-Lib levels (Figure $3 ; P=0.01$ ).

Milk fat yield was decreased with Res during both the EXP and POST periods $(P=0.02)$. During the EXP period, milk fat yield decreased by $181 \mathrm{~g} / \mathrm{d}$ but the decrease tended (treatment by period interaction, $P=0.09)$ to be greater during the POST period $(276$ $\mathrm{g} / \mathrm{d}$ ) due to continued reduced milk production and a reduction in the milk fat content of Res cows during 


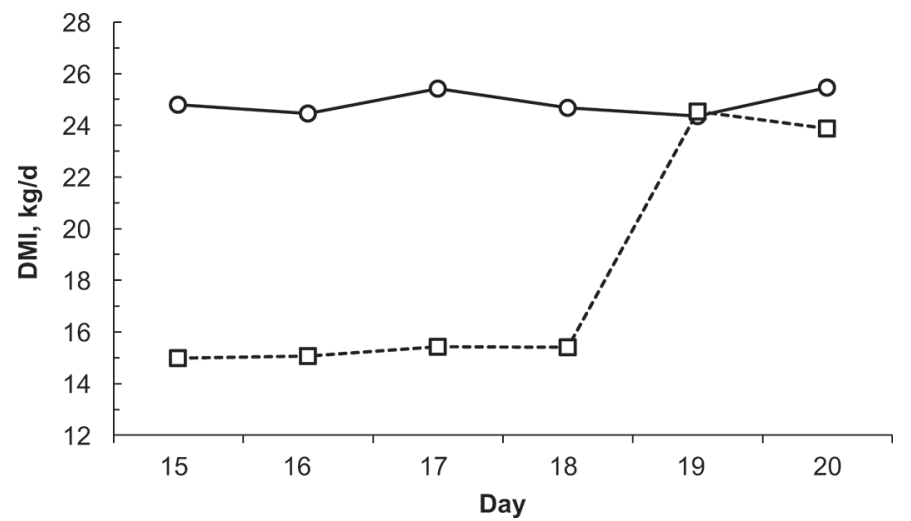

Figure 1. Changes in DMI during the experimental (d 15 to 18) and post-experimental (d 19 to 20) periods for cows fed either ad libitum $(-\mathrm{O}-$ ) or restricted to $60 \%$ of ad libitum (--- $\square---)$. Treatment, $P$ $<0.01$; treatment by period interaction, $P<0.01 ; \mathrm{SEM}=0.62$. The mean $( \pm \mathrm{SD})$ DMI during the covariate period was $25.3( \pm 2.65)$ and $23.7( \pm 1.10) \mathrm{kg} / \mathrm{d}$ for cows in the respective treatment groups.

the POST compared with the EXP period. Fat-corrected $(3.5 \%)$ milk yield followed patterns of milk and fat yields (Table 4), where differences in FCM due to Res compared with Ad-Lib were greater during POST $(-8.2 \mathrm{~kg} / \mathrm{d})$ than during EXP $(-5.9 \mathrm{~kg} / \mathrm{d})$. This may be due to the delay in the loss of milk production after the initiation of feed restriction on d 15 and the corresponding delay in recovery during d 19 and 20 after resumption of ad libitum feeding.

Feed restriction decreased $(P=0.01)$ milk protein yield by 278 and $281 \mathrm{~g} / \mathrm{d}$ during EXP and POST, respectively (Table 4). This was primarily due to a reduction in milk yield because milk protein concentration

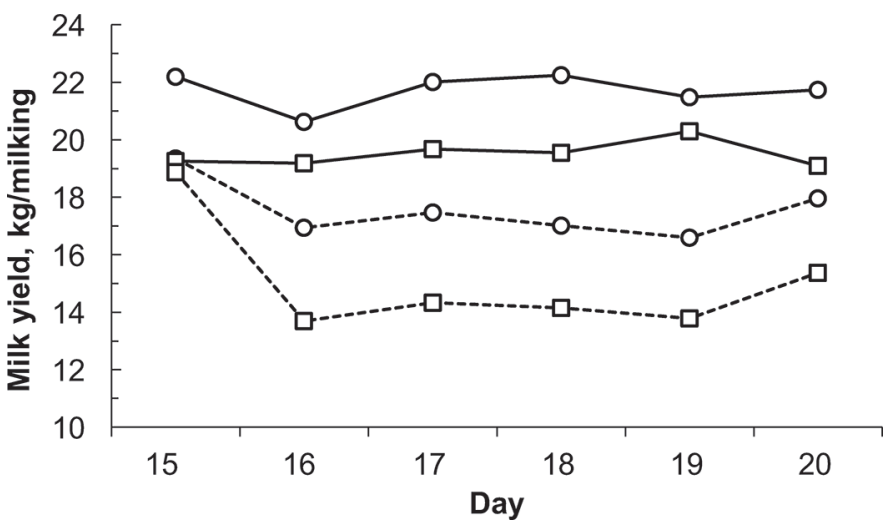

Figure 2. Changes in milk yield for the a.m. (-) and p.m. (---) milkings during the experimental (d 15 to 18) and post-experimental (d 19 to 20) periods for cows fed either ad libitum (O) or restricted to $60 \%$ of ad libitum ( $\square$ ) feed intake. Treatment by day by time (period) interaction, $P=0.05$; SEM $=0.97$. The mean $( \pm \mathrm{SD})$ milk production during the covariate period was $26.0( \pm 2.93), 15.1( \pm 1.99), 24.2$ $( \pm 1.69)$, and $14.9( \pm 1.11) \mathrm{kg} / \mathrm{d}$ for the a.m.-ad libitum, p.m.-ad libitum, a.m.-restricted, and p.m.-restricted groups, respectively.

was not affected $(P=0.18)$. We detected a trend $(P$ $=0.08)$ for reduced milk protein percent in Res during EXP. There was a treatment by day within period interaction in which milk protein yield (data not shown) was lowest at d 16 of the experiment in the Res group $(P=0.01)$.

The concentration of OS was decreased $(P=0.01)$ by 0.09 and 0.10 percentage units in the Res cows during the EXP and POST periods. Yield of OS was reduced $480 \mathrm{~g} / \mathrm{d}(P<0.01)$ by Res compared with Ad-Lib during EXP. The reduction in OS yield continued through

Table 4. Feed intake, milk yield, and milk composition in cows fed either ad libitum (Ad-Lib) or restricted to $60 \%$ of ad libitum (Res) during the experimental (EXP) period on d 15 to 18 followed by the post-experimental (POST) period when both groups were fed libitum

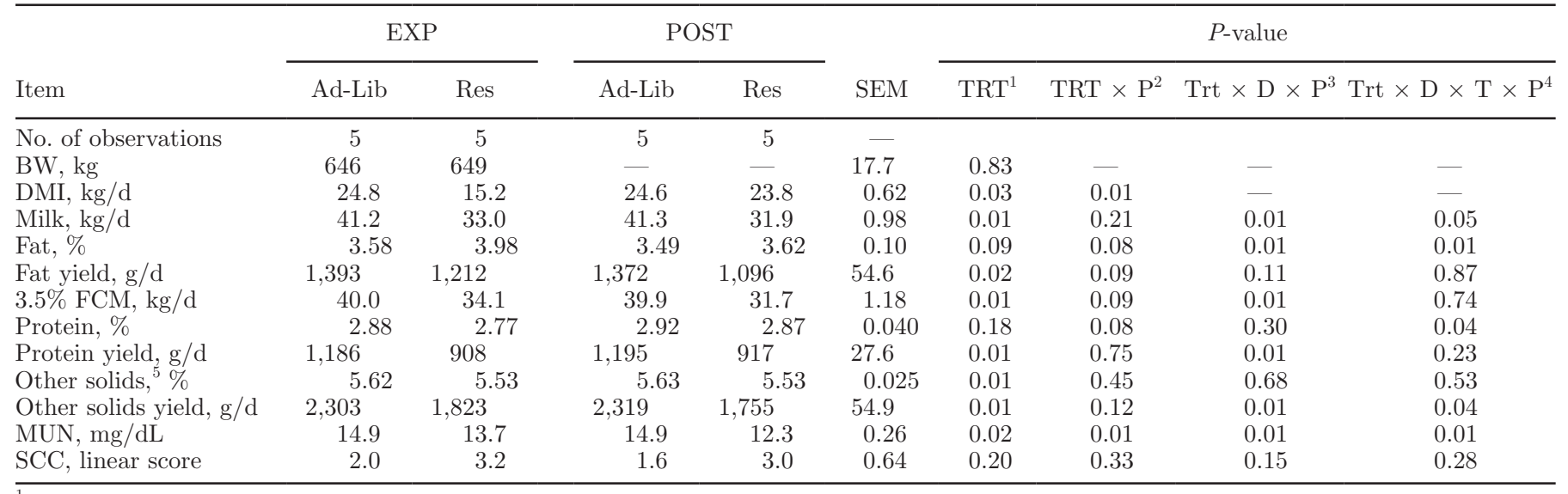

\footnotetext{
${ }^{1}$ Treatment.

${ }^{2}$ Treatment by period interaction.

${ }^{3}$ Treatment by day (period) interaction.

${ }^{4}$ Treatment by day by time (period) interaction.

${ }^{5}$ Lactose plus minerals.
} 


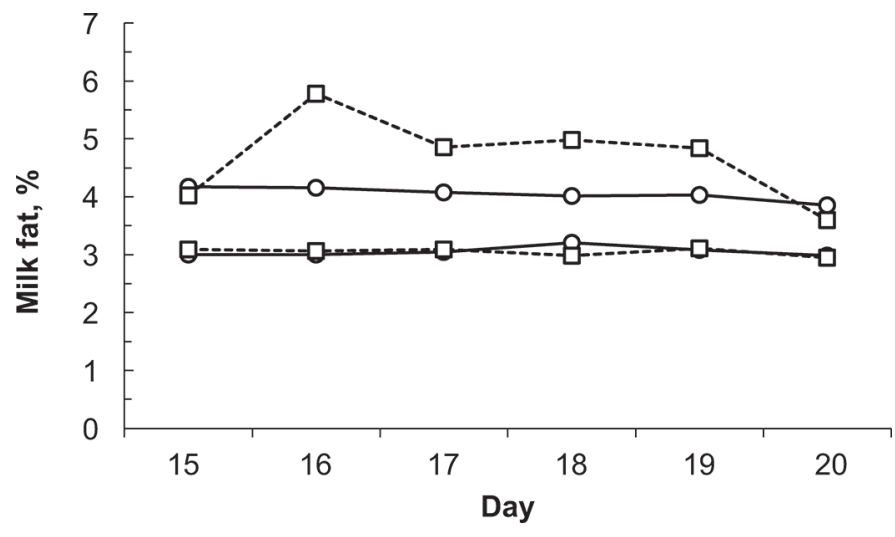

Figure 3. Changes in milk fat percent for the a.m. (-) and p.m. (--) milkings during the experimental (d 15 to 18 ) and post-experimental (d 19 to 20) periods for cows fed either ad libitum $(\bigcirc)$ or restricted to $60 \%$ of ad libitum ( $\square$ ) feed intake. Treatment by day by time (period) interaction, $P=0.01 ; \mathrm{SEM}=0.20$. The mean $( \pm \mathrm{SD})$ milk fat percent during the covariate period was $3.40( \pm 0.092), 4.25( \pm 0.322), 2.76$ $( \pm 0.210)$, and $3.95( \pm 0.349) \mathrm{kg} / \mathrm{d}$ for the a.m.-ad-libitum, p.m.-adlibitum, a.m.-restricted, and p.m.-restricted groups, respectively.

d 19 and 20 of POST as there was no treatment by period interaction $(P=0.12)$. The magnitude of the difference in OS yield was greatest on $\mathrm{d} 16$ where the EXP group produced only $725 \mathrm{~g} / \mathrm{d}$ OS [treatment by day by time (period) interaction, $P=0.04]$.

Milk urea nitrogen was reduced $(P=0.02)$ in Res $(13.7 \mathrm{mg} / \mathrm{dL})$ compared with Ad-Lib $(14.9 \mathrm{mg} / \mathrm{dL})$ with a significant carryover effect in the POST period $(P<0.01)$, when differences were even greater: 12.4 and $14.9 \mathrm{mg} / \mathrm{dL}$ in the Res and Ad-Lib treatments, respectively. The lowest concentration of MUN was observed in the p.m. milk of the Res group on d 19 of the experiment $[11.1 \mathrm{mg} / \mathrm{dL}$; treatment by day by time (period) interaction, $P=0.01]$. Reduced MUN would be expected with feed restriction because MUN reflects urinary N excretion (Jonker et al., 1998), which would be expected to be reduced because of decreased $\mathrm{N}$ intake in the Res. We detected no differences in SCC $(P=0.20)$ between Res and Ad-Lib treatments.

\section{Energy Balance and NEFA}

As expected, serum NEFA was increased $(P<0.01$, Figure 4$)$ in the Res group $(0.78 \pm 0.05 \mathrm{mEq} / \mathrm{L})$ compared with the Ad-Lib group $(0.13 \pm 0.05 \mathrm{mEq} / \mathrm{L})$ during the EXP period. The NEFA concentration in the Res group returned to that of the Ad-Lib group during POST, reflecting a treatment by period interaction $(P=0.01)$. Energy balance data are reported in Table 5 and reflect the effects of Res during EXP. The estimated energy balance was 2.2 and $-8.9 \mathrm{Mcal} / \mathrm{d}$ in the Ad-Lib and Res groups, respectively, during EXP

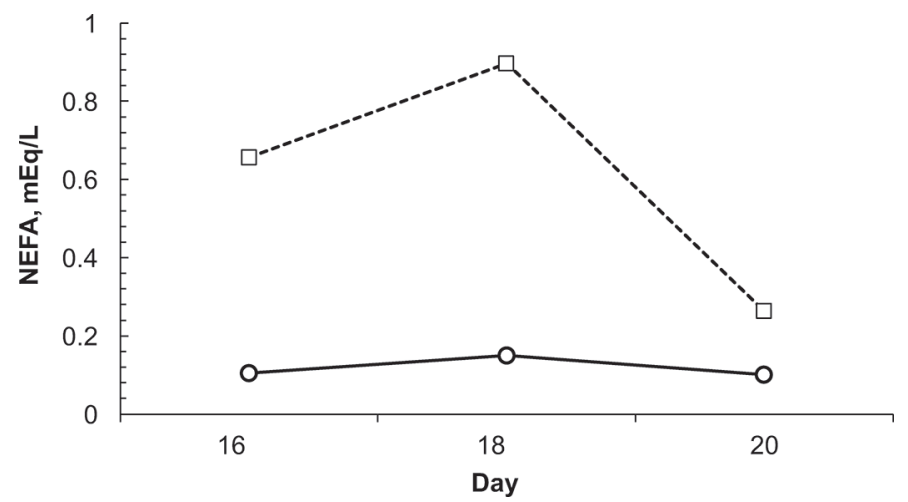

Figure 4. Changes in serum nonesterified fatty acid (NEFA) concentration during the experimental (d 15 to 18) and post-experimental (d 19 to 20) periods for cows fed either ad libitum ( $-\mathrm{O}-$ ) or restricted to $60 \%$ of ad libitum (--- $\square---$ ). Treatment by period interaction, $P$ $=0.01 ; \mathrm{SEM}=0.05$. The mean $( \pm \mathrm{SD})$ NEFA concentration during the covariate period was $0.093( \pm 0.0349)$ and $0.0598( \pm 0.00831) \mathrm{mEq} / \mathrm{L} \mathrm{d}$ for cows in the respective treatment groups.

(treatment by period interaction, $P<0.01$ ). The differences in energy balance reflected a $17.7 \mathrm{Mcal} / \mathrm{d}$ decline in energy intake $(P<0.001)$ in Res and would have been more severe if milk energy output had not been reduced in the Res compared with the Ad-Lib treatment. During POST, when both groups were fed ad libitum, energy balance was unchanged in the AdLib treatment, whereas it was $+7.4 \mathrm{Mcal} / \mathrm{d}$ in the Res group.

\section{Milk Fatty Acids}

Milk FA composition, expressed as percentage of FAME, is summarized in Table 6. The milk FA profile of the Ad-Lib cows was stable between EXP and POST. Milk fat C4:0 tended to be reduced $(P=0.10)$, whereas C6:0 and C10:0 $(P<0.01)$ and $\mathrm{C} 12: 0$ and C14:0 $(P<0.001)$ were reduced in the Res cows during EXP. For the most part, the concentrations of these FA returned to that of the Ad-Lib treatment in the POST period. Milk FA C8:0 and C14:1 were not affected ( $P$ $>0.10)$ by treatment. We detected a treatment by period interaction for C16:0 $(P<0.01)$ such that Res cows had higher concentrations during EXP but were similar to Ad-Lib during POST. Milk FA C16:1 cis-9 and $\mathrm{C} 17: 1$ cis-9 $(P<0.01)$ were increased in EXP and to a lesser extent in POST. For the C18 FA, C18:0 was not affected by Res during the EXP but was reduced from 8.4 to $5.6 \%$ of FAME during POST (treatment by period interaction, $P<0.01)$. By far, the greatest single treatment effect on individual milk FA during the EXP was for $\mathrm{C} 18: 1$ cis-9, which was $50 \%$ greater (25.3 vs. $16.8 \%$ of FAME, $P<0.01$ ) in Res compared 
Table 5. Net energy intake, energy requirements, and energy balance (Mcal/d) in cows fed either ad libitum (Ad-Lib) or restricted to 60\% of ad libitum (Res) during the experimental (EXP) period on d 15 to 18 followed by the post-experimental (POST) period when both groups were fed ad libitum on d 19 and 20

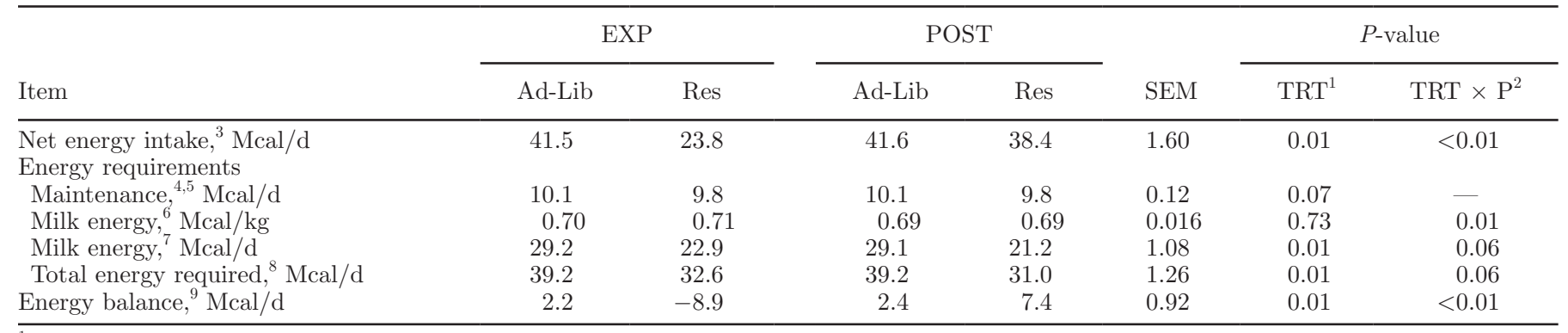

${ }^{1}$ Treatment.

${ }^{2}$ Treatment by period interaction.

${ }^{3} \mathrm{DMI}, \mathrm{kg} / \mathrm{d} \times 1.628 \mathrm{Mcal} / \mathrm{kg}$ of DM (Table 2$)$.

${ }^{4}$ Maintenance energy required, $\mathrm{Mcal} / \mathrm{d}=0.08 \times \mathrm{BW}^{0.75}$.

${ }^{5}$ Average BW $(\mathrm{kg})$ for Ad-Lib $=634( \pm 75.5)$ and Res $=606( \pm 25.4)$ measured on d 8 during preliminary period. BW measured during Res would be affected by reduced gut fill from feed restriction. Therefore, TRT $\times \mathrm{P}$ interactions for maintenance could not be calculated.

${ }^{6}$ Milk energy $(\mathrm{Mcal} / \mathrm{kg})=0.0929 \times$ fat $\%+0.0571 \times$ protein $\%+0.0395 \times($ other solids -0.70$)$.

${ }^{7}$ Milk energy $(\mathrm{Mcal} / \mathrm{d})=$ milk energy $(\mathrm{Mcal} / \mathrm{kg}) \times$ milk yield $(\mathrm{kg})$.

${ }^{8}$ Total energy required $(\mathrm{Mcal} / \mathrm{d})=$ maintenance energy $(\mathrm{Mcal} / \mathrm{d})+$ milk energy $(\mathrm{Mcal} / \mathrm{d})$.

${ }^{9}$ Energy balance $=$ net energy intake - maintenance energy requirement - milk energy.

with Ad-Lib treatment group. By d 20 of POST, C18:1 cis-9 was similar for both treatments [treatment by time (period) interaction, $P=0.59]$.
Among the groups of FA (Table 6), total trans 18:1 was unaffected by treatment during EXP and POST. Total saturated FA were reduced $(P=0.001)$ in Res

Table 6. Milk fatty acid composition (\% of FAME) ${ }^{1}$ collected on d 18 of the feed restriction period (EXP) and d 20 of post-feed restriction (POST) period

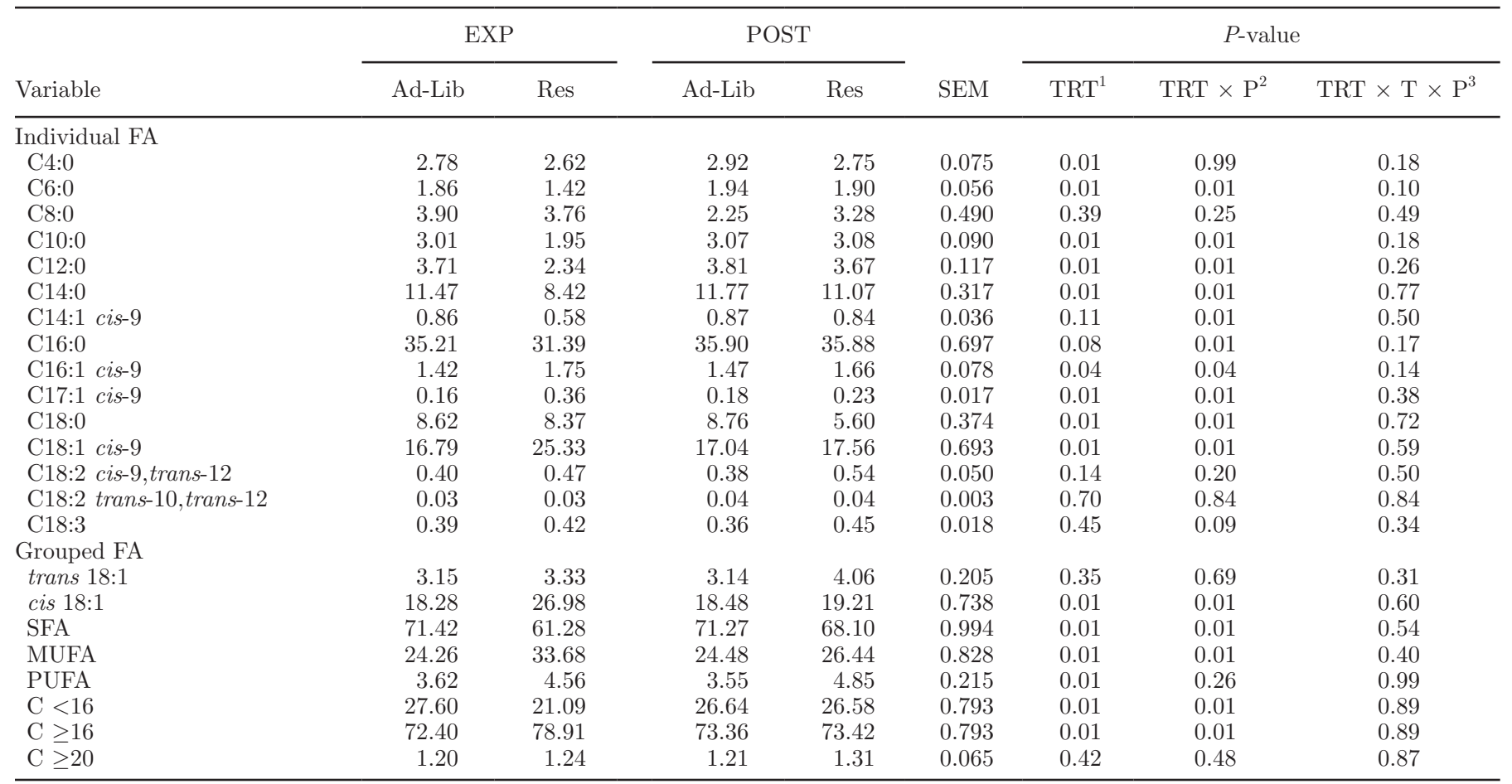

${ }^{1}$ Treatment.

${ }^{2}$ Treatment by period interaction.

${ }^{3}$ Treatment by time (period) interaction. 
during EXP but these differences largely disappeared in POST. Monounsaturated FA were increased $(P<$ 0.001 ) from 24.4 to $33.7 \%$ during EXP, largely as a result of the increase in $\mathrm{C} 18: 1$ cis-9. There were small but significant $(P=0.01)$ increases in total PUFA (C18:2 and C18:3) during EXP and POST in the Res treatment. Overall, the total short-chain FA $(\mathrm{C}<16)$ decreased $(P<0.01)$ by 6.5 percentage units and $\mathrm{C}$ $\geq 16$ increased by a similar amount in the Res treatment during EXP. For all groups of FA, no difference between Res and Ad-Lib treatments were detected by d 20 of the POST period.

\section{Mammary Lipogenic Genes}

Gene expression data are represented as fold changes in Table 7 and represent covariate-adjusted means using d-14 data from the preliminary period when all cows were fed ad libitum. In this study, genes were selected based on their role in regulation of mammary lipogenesis: (1) $L P L$ is associated with importing FA into the cells, (2) ACACA, FASN, and SCD1 are associated with de novo fatty acid synthesis and desaturation, (3) GPAM and AGPAT6 are associated with triglyceride synthesis, (4) FABP3 is associated with acetate and fatty acid activation and intracellular transport, (5) PPARG and SREBF1 are associated with regulation of transcription, and (6) BTN1A1 is associated with lipid droplet formation (Bernard et al., 2008).

Regardless of period, feed restriction resulted in downregulation of ACACA $(P=0.02), G P A M(P=$ $0.05), S C D 1(P<0.01)$, FABP3 $(P<0.01), L P L(P$ $=0.04)$, and $S R E B P 1(P=0.02)$ and tended toward downregulation of FASN $(P=0.06)$. Feed restriction did not affect the expression of AGPAT6, BTN1A1, or PPARG. The only significant treatment by period interaction $(P=0.05)$ was for $A C A C A$, and there was a trend for $F A S N(P=0.09)$, where the relative fold difference in $A C A C A$ was reduced and that for FASN was increased between Res and Ad-Lib groups during POST compared with EXP. For GPAM, SCD1, FABP3, $L P L$, and $S R E B F$, relative fold differences observed during POST were similar to those observed in EXP, suggesting that there was a carryover effect from feed restriction. We were able to detect treatment by day within period interactions $(P \leq 0.05)$ for the expression of GPAM, LPL, BTN1A1, and SREBF1 (Figures 5, 6, 7 , and 8 , respectively). In general, the decline in expression of these genes in the Res group reached a nadir on d 16 or 17 and then began to increase on d 19 after feed restriction ended. Conversely, in the Ad-Lib group, relative gene expression of GPAM, BTNA1, and $L P L$ appeared to increase (Figures 5, 6, and 7, respectively). A notable exception was for $S R E B F 1$, where both Res and Ad-Lib groups declined from d 15 to 16 and then increased in the Ad-Lib group thereafter, whereas the Res group remained low.

\section{DISCUSSION}

In this study, feed restriction was used as a tool to induce a rapid metabolic change and subsequent alterations in milk yield, composition, and FA profile, with the hypothesis that feed restriction would induce corresponding changes in mammary lipogenic gene expression. Feed restriction resulted in a 39\% reduction in DMI during the 4-d feed restriction period. This resulted in $20,13,23$, and $21 \%$ reductions in yields of milk, fat, protein, and other solids, respectively, suggesting that energy and protein supply was severely limited.

Table 7. Effect of feed restriction (Res) on covariate-adjusted fold-change [relative to the ad libitom (AdLib) treatment] differences in gene expression of selected mammary lipogenic genes during the feed restriction period (EXP) and post-feed restriction (POST) period

\begin{tabular}{|c|c|c|c|c|c|c|c|c|}
\hline \multirow[b]{2}{*}{ Gene } & \multicolumn{2}{|c|}{ EXP } & \multicolumn{2}{|c|}{ POST } & \multirow[b]{2}{*}{ SEM } & \multicolumn{3}{|c|}{$P$-value } \\
\hline & Ad-Lib & Res & Ad-Lib & Res & & $\mathrm{TRT}^{1}$ & $\mathrm{TRT} \times \mathrm{P}^{2}$ & $\mathrm{TRT} \times \mathrm{D} \times \mathrm{P}^{3}$ \\
\hline$A C A C A$ & 1.28 & 0.57 & 1.96 & 0.75 & 0.250 & 0.02 & 0.05 & 0.23 \\
\hline$F A S N$ & 2.21 & 1.63 & 3.93 & 2.32 & 0.485 & 0.06 & 0.09 & 0.10 \\
\hline AGPAT6 & 1.83 & 1.31 & 2.70 & 1.71 & 0.376 & 0.12 & 0.24 & 0.02 \\
\hline$G P A M$ & 1.78 & 0.96 & 2.53 & 1.49 & 0.339 & 0.05 & 0.57 & 0.03 \\
\hline$S C D 1$ & 0.96 & 0.46 & 1.46 & 1.11 & 0.131 & 0.01 & 0.38 & 0.75 \\
\hline FABP3 & 1.19 & 0.56 & 1.28 & 0.78 & 0.132 & 0.01 & 0.50 & 0.10 \\
\hline$L P L$ & 1.50 & 0.75 & 2.06 & 1.33 & 0.296 & 0.04 & 0.95 & 0.03 \\
\hline$B T N 1 A 1$ & 2.38 & 2.07 & 4.96 & 3.43 & 0.646 & 0.16 & 0.12 & 0.02 \\
\hline$P P A R G$ & 1.89 & 1.44 & 2.91 & 2.60 & 0.561 & 0.53 & 0.86 & 0.92 \\
\hline$S R E B F 1$ & 0.85 & 0.55 & 1.32 & 0.69 & 0.180 & 0.02 & 0.16 & 0.01 \\
\hline
\end{tabular}

${ }^{1}$ Treatment.

${ }^{2}$ Treatment by period interaction.

${ }^{3}$ Treatment by day (period) interaction. 


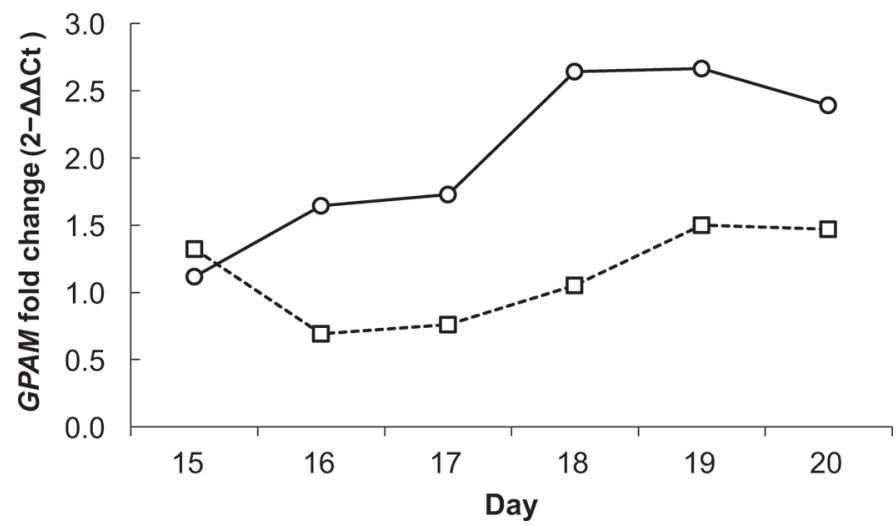

Figure 5. Changes in GPAM gene expression during the experimental (d 15 to 18) and post-experimental (d 19 to 20) periods for cows fed either ad libitum (- - - ) or restricted to $60 \%$ of ad libitum $(---\square---)$. Treatment, $P=0.03$; treatment by period interaction, $P=$ $0.56 ; \mathrm{SEM}=0.33$. The mean $( \pm \mathrm{SD})$ relative GPAM gene expression during the covariate period was $1.03( \pm 0.191)$ and $1.88( \pm 0.540)$ for cows in the respective treatment groups.

These results were similar to those observed over the 3 -d restricted period reported by Nielsen et al. (2003), where feed was restricted to $65 \%$ of ad libitum intake in cows averaging 50 DIM. Similar to our results, they showed an increase in milk fat concentration. In the current study, calculated energy balances and serum NEFA concentration in the current study confirmed that a negative energy balance was induced.

In addition to feed restriction, the eating pattern was markedly different between Res and Ad-Lib cows. Although we did not collect the exact times of eating during the experiment, the Res cows generally consumed all of their daily feed allotment during the first 5 to

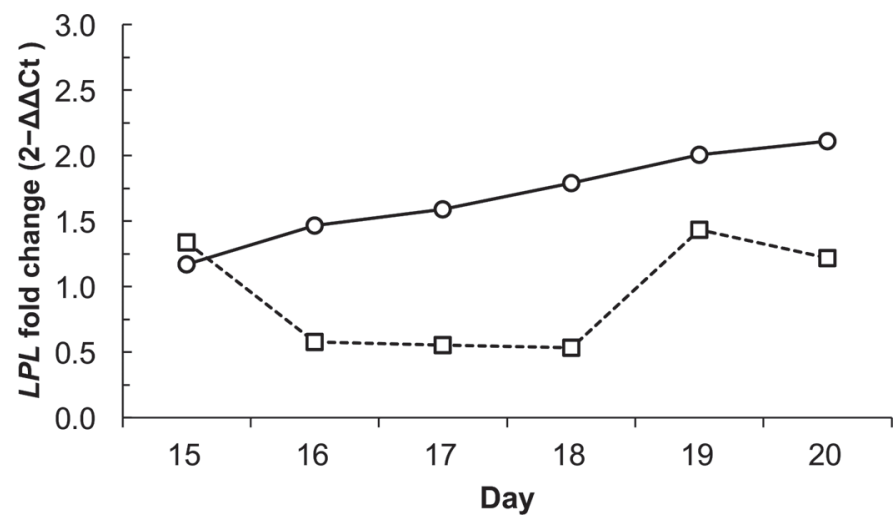

Figure 6. Changes in $L P L$ gene expression during the experimental (d 15 to 18) and post-experimental (d 19 to 20) periods for cows fed either ad libitum (-O-) or restricted to $60 \%$ of ad libitum (--- $\square---)$ Treatment, $P=0.04$; treatment by period interaction, $P=0.95$; SEM $=0.30$. The mean $( \pm \mathrm{SD})$ relative $L P L$ gene expression during the covariate period was $1.35( \pm 0.397)$ and $1.28( \pm 0.787)$ for cows in the respective treatment groups.

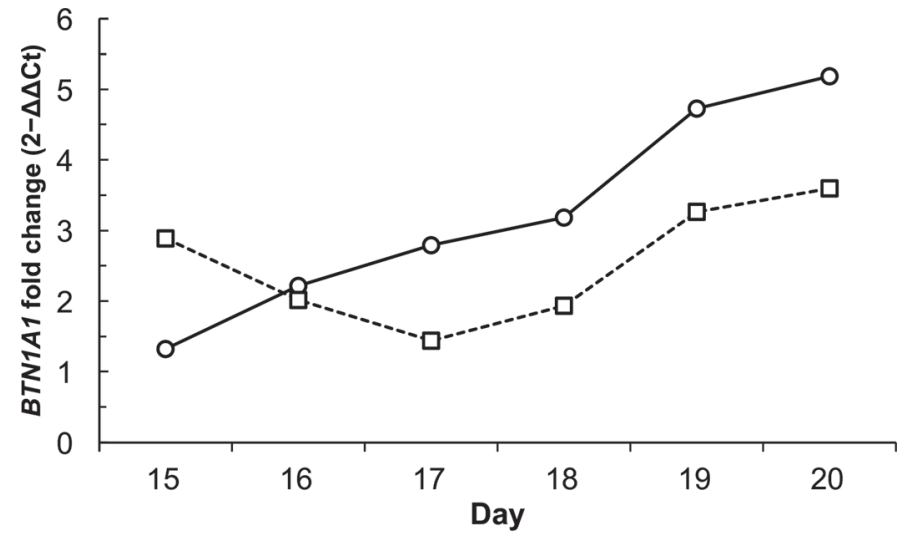

Figure 7. Changes in BTN1A1 gene expression during the experimental (d 15 to 18) and post-experimental (d 19 to 20) periods for cows fed either ad libitum (- - - ) or restricted to $60 \%$ of ad libitum (--- $\square$---). Treatment, $P=0.02$; treatment by period interaction, $P=$ 0.12 ; $\mathrm{SEM}=0.64$. The mean $( \pm \mathrm{SD})$ relative BTN1A1 gene expression during the covariate period was $1.25( \pm 0.411)$ and $1.50( \pm 1.023)$ for cows in the respective treatment groups.

$6 \mathrm{~h}$ after feed was offered at $0900 \mathrm{~h}$ such that there was no feed refusal by the time of the p.m. milking at $1600 \mathrm{~h}$. In this experiment, cows would cycle from a fed state at the time that feed was first offered $(0900 \mathrm{~h})$ to a fasted state after the daily allotment was consumed (from roughly 1500 to $0900 \mathrm{~h}$ ). Further, milk production did not quickly recover once Res cows returned to ad libitum feeding on d 19 and 20 even though they consumed as much dry matter as the Ad-Lib cows. The combined effects of feed restriction on NEFA, energy balance, milk production, and yields of milk components suggested a severe metabolic change.

The induced negative energy balance in this experiment and those reported in other feed restriction exper-

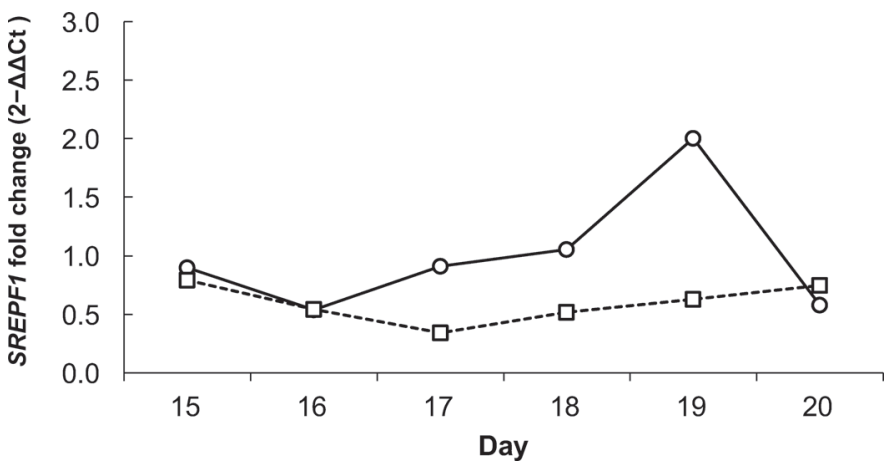

Figure 8. Changes in SREPF1 gene expression during the experimental (d 15 to 18) and post-experimental (d 19 to 20) periods for cows fed either ad libitum (- - - ) or restricted to $60 \%$ of ad libitum (--- $\square---)$. Treatment, $P=0.01$; treatment by period interaction, $P=$ 0.15 ; $\mathrm{SEM}=0.18$. The mean $( \pm \mathrm{SD})$ relative $S R E P F 1$ gene expression during the covariate period was $1.32( \pm 0.525)$ and $1.09( \pm 0.928)$ for cows in the respective treatment groups. 
iments (Nielsen et al., 2003; Moyes et al., 2009; Gross et al., 2011a) is in sharp contrast to that observed in dairy cows in early lactation that have continuous access to feed but do not eat to meet energy requirements. Gross et al. (2011a) reported major differences in terms of production and BW losses in cows with a feed restriction-induced negative energy balance at $\sim 98 \mathrm{~d}$ postpartum compared with cows in early lactation. In early lactation, milk yield increases in spite of the negative energy balance, whereas milk yield declines with temporary feed restriction-induced negative energy balance. During early lactation negative energy balance, milk protein and, to a greater degree, milk fat concentration decrease with increasing DIM and increased energy balance (Kay et al., 2005; Gross et al., 2011a).

We observed a trend for increased milk fat concentration with Res, with no change in milk protein concentration. Similarly, Nielsen et al. (2003) noted a significant increase in milk fat percent by feed restriction and Gross et al. (2011a) reported a tendency $(P<0.1)$ for higher milk fat percent in restricted cows $(4.63 \%)$ than in control cows $(4.38 \%)$. In our study, milk fat percent was only increased during the afternoon milking in the Res treatment, with the greatest response coming on $\mathrm{d} 16$, the second day of feed restriction (5.8 and $4.2 \%$ milk fat in the Res and Ad-Lib groups, respectively). All cows in this study were fed at $0900 \mathrm{~h}$ and milked at $1600 \mathrm{~h}$; therefore, there was only a 7 -h gap between feeding and afternoon milking. It is possible that during this time, there was an increased supply of lipid precursors to the mammary gland, including absorbed rumen VFA in conjunction with the additive effect of digested feed. As a result, milk fat percentage was increased in the p.m. milk of Res cows during the EXP period, possibly due to an increase in the proportion of de novo FA $(<\mathrm{C} 16)$. In contrast to feed restriction induced changes in milk fat concentrations, the decline in milk fat concentration that correspond with increasing energy balance in early lactation are generally much greater. Gross et al. (2011b) reported a 1.43-percentage-unit decline in milk fat between wk 1 and wk 6 postpartum compared with a 0.53 -percentage-unit increase in milk fat during the first week of energy restriction, even though the energy balance was more negative in energy-restricted cows in mid lactation.

During negative energy balance, milk FA profile reflects the mobilization of body stores, as indicated by increased NEFA concentration. Nonesterified fatty acids are rich sources of long-chain FA such as oleic acid (18:1 cis-9), stearic acid (18:0), and palmitic acid (16:0) (Stoop et al., 2009; Hostens et al., 2012). Oleic acid is the most abundant fatty acid found in body fat depots; therefore, when a lactating cow is in negative energy balance and mobilizing body fat, this FA will be abundantly present in the milk, suggesting its use as a potential biomarker for negative energy balance (Rukkwamsuk et al., 2000; Jorjong et al., 2014). We observed a doubling of milk oleic acid during feed restriction, a 6.5-percentage-unit reduction in $\mathrm{C} 4$ to $\mathrm{C} 14$ $\mathrm{FA}$, and a corresponding increase in $\geq \mathrm{C} 16 \mathrm{FA}$ in milk fat with feed restriction. These results were similar to the changes in milk FA composition reported during early lactation (Kay et al., 2005; Gross et al., 2011b) negative energy balance and feed restriction-induced negative energy balance studies (Gross et al., 2011b).

Nutritional regulation is a major factor that affects mammary lipogenic gene expression (Baumgard et al., 2002; Bernard et al., 2008; Kadegowda et al., 2010). In a study conducted in goats by Ollier et al. (2007), a 48-h fast resulted in downregulation of genes, particularly those involved in milk lipid, protein, and lactose metabolism as a response from mammary gland to the lack of nutrient supply. In turn, the downregulation of selected genes reflected the pathways related to de novo synthesis of FA in the mammary gland. Feed restriction in our study caused an abrupt downregulation in $A C A C A, F A B P 3, L P L, G P A M$, SREBF1, and SCD1, with a tendency for downregulation in FASN expression that occurred within the first 1 to $2 \mathrm{~d}$ after initiation of feed restriction that corresponded with the reduced milk production and milk fat yield.

In part, the decline in de novo synthesized fatty acids could be attributed to a reduction in absorbed VFA precursors from reduced rumen fermentation. Furthermore, Luick and Smith (1963) explained that during feed restriction, the mammary gland is incapable of utilizing $\mathrm{BHB}$, which is a precursor of de novo synthesis of fatty acids that is elevated during negative energy balance conditions. From that, it could be suggested that feed restriction stimulates the pathway involved in FA uptake from circulating NEFA and suppresses the de novo synthesis pathway in the mammary gland due to lack of nutrients (Dessauge et al., 2011). However, all lipogenic genes were upregulated, including those associated with uptake of circulating FA ( $L P L$, $F A B P 3)$ during the EXP period, including SREBPF1, which is commonly thought to be the most important general transcription factor regulator of milk fat synthesis (Rudolph et al., 2007). Fatty acid profiles appeared to return to normal by d 20 during the POST period, but genes affected by Res had not returned to Ad-Lib treatment levels by that time. Feed restrictioninduced changes in milk FA profiles were similar to those observed during negative energy balance in early lactation. However, the differences in milk production and milk composition responses to negative energy bal- 
ance caused by feed restriction compared with those observed in early lactation suggest that there are limits to the use of the feed restriction model to mimic the metabolic responses that occur naturally at the beginning of lactation.

Maningat et al. (2007) first tested the concept of using milk fat-associated RNA using human breast milk and reported a mean RNA abundance of content of 4.5 $\mu \mathrm{g} / \mathrm{mL}$ of milk. Assuming a mean fat content of $3.66 \%$, the corresponding value in cows was equivalent to 0.26 $\mu \mathrm{g}$ of $\mathrm{RNA} / \mathrm{mL}$ of milk. This lower value was not unexpected, as previous studies (Janssen and Walstra, 1982; Huston and Patton, 1990) had shown that fat globules in human breast milk had a much greater proportion of cytosolic crescents than in cow milk. Using frequent sampling (1 to $3 \mathrm{~h}$ ), Maningat et al. (2007) were able to demonstrate temporal effects on $\alpha$-lactalbumin gene expression patterns. However, we unable to detect time of milking effects on lipogenic gene expression in the current study. This might be because of a lack of sensitivity in measurement or from the extended period between milkings compared with the frequent sampling by Maningat et al. (2007). Subsequent transcriptome analysis in a later study (Maningat et al., 2009) revealed expression of genes that was consistent with that of mammary epithelial cells.

Cánovas et al. (2014) compared various sources of RNA for measurement of gene expression in the bovine mammary gland, including (1) mammary gland tissue obtained by biopsy, (2) milk somatic cells, (3) laser micro-dissected mammary epithelial cells, (4) milk fat globules, and (5) antibody-captured milk mammary epithelial cells. Those authors suggested that RNA isolated from both milk fat globules and milk somatic cells were the most representative of mammary gland tissue as alternatives to mammary biopsy.

Brenaut et al. (2012) compared the RNA extracted from both the milk fat globule and mammary alveolar parenchyma in goats using microarray technology, and they confirmed the results by running reversetranscription quantitative PCR. The authors reported that the RNA sources shared 89 to $93.5 \%$ of the highlighted genes, particularly those encoding milk proteins and enzymes involved in fat synthesis. Furthermore, to determine whether the RNA from milk fat globules was contaminated with immune cells known to associate with the milk fat globule during cream separation, Brenaut et al. (2012) used quantitative PCR with specific markers for immune cells, such as CD68 for macrophages and CD3e for lymphocyte. They found that CD3e message was absent in milk fat globules but CD68 was present in very low amounts, suggesting that RNA contamination might be an issue in does that were free of mastitis.

\section{CONCLUSIONS}

In this study, downregulation of selected mammary lipogenic genes was demonstrated during the first 1 to $2 \mathrm{~d}$ following the initiation of feed restriction in dairy cows. The decreases in gene expression, milk yield, and milk fat content were consistent with previously published work regarding the effects of feed restrictioninduced negative energy balance on milk fat synthesis and lipogenic gene expression using tissue obtained by mammary biopsy as a source of RNA. In conjunction with previous studies that reported on the isolation of RNA from milk fat, we conclude that short-term temporal effects on mammary lipogenic gene expression can be measured using this approach.

\section{ACKNOWLEDGMENTS}

The authors thank Cairo University and Egyptian Mission Sector for providing partial funding for this experiment. In addition, the authors thank Michael Dwyer, Brian Spielman, and the entire staff at the Central Maryland Research and Education Center (CMREC, Clarksville) for their assistance in feeding, sample collection, and care of the experimental animals used in this study.

\section{REFERENCES}

Baumgard, L. H., E. Matitashvili, B. A. Corl, D. A. Dwyer, and D. E. Bauman. 2002. Trans-10, cis-12 conjugated linoleic acid decreases lipogenic rates and expression of genes involved in milk lipid synthesis in dairy cows. J. Dairy Sci. 85:2155-2163.

Bernard, L., C. Leroux, and Y. Chilliard. 2008. Expression and nutritional regulation of lipogenic genes in the ruminant lactating mammary gland. Adv. Exp. Med. Biol. 606:67-108.

Bionaz, M., and J. J. Loor. 2007. Identification of reference genes for quantitative real-time PCR in the bovine mammary gland during the lactation cycle. Physiol. Genomics 29:312-319.

Bionaz, M., and J. J. Loor. 2008a. ACSL1, AGPAT6, FABP3, LPIN1, and SLC27A6 are the most abundant isoforms in bovine mammary tissue and their expression is affected by stage of lactation. J. Nutr. 138:1019-1024.

Bionaz, M., and J. J. Loor. 2008b. Gene networks driving bovine milk fat synthesis during the lactation cycle. BMC Genomics 9:366.

Brenaut, P., R. Bangera, C. Bevilacqua, E. Rebours, C. Cebo, and P. Martin. 2012. Validation of RNA isolated from milk fat globules to profile mammary epithelial cell expression during lactation and transcriptional response to a bacterial infection. J. Dairy Sci. 95:6130-6144.

Cánovas, A., G. Rincon, C. Bevilacqua, A. Islas-Trejo, P. Brenaut, R. C. Hovey, M. Boutinaud, C. Morgenthaler, M. K. VanKlompenberg, P. Martin, and J. F. Medrano. 2014. Comparison of five different RNA sources to examine the lactating bovine mammary gland transcriptome using RNA-Sequencing. Sci. Rep. 4:5297.

Christie, W. W. 1982. Lipid Analysis. 2nd ed. Pergamon Press, Oxford, UK.

Dessauge, F., V. Lollivier, B. Ponchon, R. Bruckmaier, L. Finot, S. Wiart, E. Cutullic, C. Disenhaus, S. Barbey, and M. Boutinaud. 2011. Effects of nutrient restriction on mammary cell turnover and mammary gland remodeling in lactating dairy cows. J. Dairy Sci. 94:4623-4635. 
Farr, V. C., K. Stelwagen, L. R. Cate, A. J. Molenaar, T. B. McFadden, and S. R. Davis. 1996. An improved method for the routine biopsy of bovine mammary tissue. J. Dairy Sci. 79:543-549.

Gander, G. W., R. G. Jensen, and J. Sampugna. 1962. Analysis of milk fatty acids by gas-liquid chromatography. J. Dairy Sci. 45:323-328.

Gross, J., H. A. van Dorland, R. M. Bruckmaier, and F. J. Schwarz. 2011a. Performance and metabolic profile of dairy cows during a lactational and deliberately induced negative energy balance with subsequent re-alimentation. J. Dairy Sci. 94:1820-1830.

Gross, J., H. A. van Dorland, R. M. Bruckmaier, and F. J. Schwarz. 2011b. Milk fatty acid profile related to energy balance in dairy cows. J. Dairy Res. 78:479-488.

Hostens, M., V. Fievez, J. L. M. R. Leroy, J. Van Ranst, B. Vlaeminck, and G. Opsomer. 2012. The fatty acid profile of subcutaneous and abdominal fat in dairy cows with left displacement of the abomasum. J. Dairy Sci. 95:3756-3765.

Huston, G. E., and S. Patton. 1990. Factors related to the formation of cytoplasmic crescents on milk fat globules. J. Dairy Sci. 73:2061-2066.

Janssen, M. M. T., and P. Walstra. 1982. Cytoplasmic remnants in milk of certain species. Neth. Milk Dairy J. 36:365-368.

Jonker, J. S., R. A. Kohn, and R. A. Erdman. 1998. Using milk urea nitrogen to predict nitrogen excretion and utilization efficiency in lactating dairy cows. J. Dairy Sci. 81:2681-2692.

Jorjong, S., A. T. M. van Knegsel, J. Verwaeren, M. Val Lahoz, R. M. Bruckmaier, B. De Baets, B. Kemp, and V. Fievez. 2014. Milk fatty acids as possible biomarkers to early diagnose elevated concentrations of blood plasma non-esterified fatty acids in dairy cows. J Dairy Sci. 97:7054-7064.

Kadegowda, A. K. G., E. E. Connor, B. B. Teter, J. Sampugna, P. Delmonte, L. S. Piperova, and R. A. Erdman. 2010. Dietary trans fatty acid isomers differ in their effects on mammary lipid metabolism as well as lipogenic gene expression in lactating mice. J. Nutr. 140:919-924.

Kay, J. K., W. J. Weber, C. E. Moore, D. E. Bauman, L. B. Hansen, H. Chester-Jones, B. A. Crooker, and L. H. Baumgard. 2005. Effects of week of lactation and genetic selection for milk yield on milk fatty acid composition in Holstein cows. J. Dairy Sci. 88:3886-3893

Littell, R. C., G. A. Milliken, W. W. Stroup, and R. D. Wolfinger. 1996. SAS System for Mixed Models. SAS Inst., Cary, NC.

Livak, K. J., and T. D. Schmittgen. 2001. Analysis of relative gene expression data using real time quantitative PCR and the $2-{ }^{\Delta \Delta \mathrm{Ct}}$ method. Methods 25:402-408.

Loor, J. J., H. M. Dann, R. E. Everts, R. Oliveira, C. A. Green, N. A. Guretzky, S. L. Rodriguez-Zas, H. A. Lewin, and J. K. Drackley. 2005. Temporal gene expression profiling of liver from periparturient dairy cows reveals complex adaptive mechanisms in hepatic function. Physiol. Genomics 23:217-226.

Luick, J. R., and L. M. Smith. 1963. Fatty acid synthesis during fasting and bovine ketosis. J. Dairy Sci. 46:1251-1255.

Maningat, P. D., P. Sen, M. Rijnkels, A. L. Sunehag, D. L. Hadsell, M. Bray, and M. W. Haymond. 2009. Gene expression in the human mammary epithelium during lactation: The milk fat globule transcriptome. Physiol. Genomics 37:12-22.
Maningat, P. D., P. Sen, A. L. Sunehag, D. L. Hadsell, and M. W. Haymond. 2007. Regulation of gene expression in human mammary epithelium: Effect of breast pumping. J. Endocrinol. 195:503-511.

Moyes, K. M., J. K. Drackley, J. L. Salak-Johnson, D. E. Morin, J. C. Hope, and J. J. Loor. 2009. Dietary-induced negative energy balance has minimal effects on innate immunity during a Streptococcus uberis mastitis challenge in dairy cows during mid-lactation. J. Dairy Sci. 92:4301-4316.

Moyes, K. M., T. Larsen, P. Sørensen, and K. L. Ingvartsen. 2014. Changes in various metabolic parameters in blood and milk during experimental Escherichia coli mastitis for primiparous Holstein dairy cows during early lactation. J. Anim. Sci. Biotechnol. 5:47.

Nielsen, N. I., K. L. Ingvartsen, and T. Larsen. 2003. Diurnal variation and the effect of feed restriction on plasma and milk metabolites in TMR-fed dairy cows. J. Vet. Med. A Physiol. Pathol. Clin. Med. 50:88-97.

NRC. 2001. Nutrient Requirements of Dairy Cattle. 7th rev. ed. Natl. Acad. Press, Washington, DC.

Ollier, S., C. Robert-Granié, L. Bernard, Y. Chilliard, and C. Leroux. 2007. Mammary transcriptome analysis of food-deprived lactating goats highlights genes involved in milk secretion and programmed cell death. J. Nutr. 137:560-567.

Piperova, L. S., J. Sampugna, B. B. Teter, K. F. Kalscheur, M. P. Yurawecz, Y. Ku, K. M. Morehouse, and R. A. Erdman. 2002 Duodenal and milk trans octadecenoic acid and conjugated linoleic acid (CLA) isomers indicate that postabsorptive synthesis is the predominant source of cis-9 containing CLA in lactating dairy cows. J. Nutr. 132:1235-1241.

Quiroz-Rocha, G. F., S. LeBlanc, T. Duffield, D. Wood, K. E. Leslie, and R. M. Jacob. 2009. Evaluation of pre-partum serum cholesterol and fatty acids concentrations as predictors of postpartum retention of the placenta in dairy cows. J. Am. Vet. Med. Assoc. 234:790-793.

Rudolph, M. C., J. L. McManaman, T. Phang, T. Russell, D. J. Kominsky, N. J. Serkova, T. Stein, S. M. Anderson, and M. C. Neville. 2007. Metabolic regulation in the lactating mammary gland: A lipid synthesizing machine. Physiol. Genomics 28:323-336.

Rukkwamsuk, T., M. J. H. Geelen, T. A. M. Kruip, and T. Wensing. 2000. Interrelation of fatty acid composition in adipose tissue, serum, and liver of dairy cows during the development of fatty liver postpartum. J. Dairy Sci. 83:52-59.

Samková, E., J. Špička, M. Pešek, T. Pelikánová, and O. Hanuš. 2012. Animal factors affecting fatty acid composition of cow milk fat: A review. S. Afr. J. Anim. Sci. 42:83-100.

Stoop, W. M., H. Bovenhuis, J. M. L. Heck, and J. A. M. van Arendonk. 2009. Effect of lactation stage and energy status on milk fat composition of Holstein-Friesian cows. J. Dairy Sci. 92:1469-1478.

Vyas, D., U. Moallem, B. B. Teter, A. R. K. Fardin-Kia, and R. A. Erdman. 2013. Milk fat responses to butterfat infusion during conjugated linoleic acid-induced milk fat depression in lactating dairy cows. J. Dairy Sci. 96:2387-2399.

Wooding, F. B. P.. M. Peaker, and J. L. Linzell. 1970. Theories of milk secretion: Evidence from the electron microscopic examination of milk. Nature 226:762-764 